\title{
Analisis Laporan Arus Kas Untuk Menilai Kinerja Keuangan Perusahaan Farmasi
}

\author{
Meyliza dan Desi Efrianti \\ Program Studi Akuntansi, Institut Bisnis dan Informatika Kesatuan \\ Bogor, Indonesia \\ E-Mail: defrianti.kesatuan@gmail.com
}

\begin{abstract}
The purpose of this research is to determine the financial performance by using cash flow statement on pharmaceutical company that listed on Indonesia Stock Exchange period 2017-2019. This research is using descriptive qualitative method to describing analysis of cash flow on financial performance. Cash flow statement analysis is the independent variable and financial performance as the dependent variable. The results of this research is showing that based on the most calculations of cash flow ratios, PT Kalbe Farma Tbk has better financial performance. PT Kimia Farma (Persero) Tbk almost always shows lower financial performance. This is because PT Kimia Farma (Persero) has a negative operating cash flow. It is expected that all companies could improve their financial performance again for the coming year. The presentation of the cash flow statement of all pharmaceutical company that were studied using a direct method. Cash flow information from the company's operations is classified into cash inflows and cash outflows. Furthermore, cash inflows and cash outflows are broken down into further specified according their type.
\end{abstract}

Keywords: Cash Flow, Financial Performance, Cash Flow Ratio

\section{PENDAHULUAN}

Sub sektor farmasi sangat berpengaruh untuk menunjang sumber daya manusia yang kuat dan berkualitas. Beberapa perusahaan farmasi telah terdaftar di Bursa Efek Indonesia. Seluruh perusahaan yang telah listing di Bursa Efek Indonesia memiliki kewajiban untuk mempublikasikan laporan keuangan. Melalui laporan keuangan yang dianalisis, para pemangku kepentingan dapat menilai kinerja keuangan perusahaan. Pemangku kepentingan yang dimaksud yaitu pihak manajemen, pemberi pinjaman atau kreditor, investor, para pemasok, pemerintah, dan pelanggan. Menurut Fahmi (2014, 2), terdapat dua penilaian yang dapat dijadikan sebagai acuan dalam melihat suatu badan usaha menjalankan kaidah-kaidah manajemen, yaitu sisi kinerja keuangan (financial performance) dan kinerja non keuangan (non financial performance).

Salah satu cara untuk menilai kinerja keuangan yaitu melalui laporan arus kas. Menurut Dwi Prastowo (2014, 31-32) informasi pada laporan arus kas juga berfokus pada kebutuhan kas pada setiap aktivitas operasi, investasi, dan pendanaan yang dilakukan oleh perusahaan. Laporan arus kas diklasifikasikan menjadi tiga aktivitas, yaitu arus kas operasional (Operational Cash Flow), aktivitas pembiayaan (Financing Cash Flow), dan arus kas investasi (Investing Cash Flow). Arus kas mengindikasikan bagaimana entitas tersebut memperoleh dan menggunakan kas, termasuk informasi mengenai pinjaman dan pembayaran utang, dividen tunai atau distribusi lainnya kepada investor, dan faktor lainnya yang dapat mempengaruhi likuiditas atau solvabilitas entitas.

Penelitian akan dilakukan pada perusahaan yang telah listing di Bursa Efek Indonesia dan telah masuk ke dalam sektor farmasi. Hal ini dikarenakan pentingnya sektor farmasi di Indonesia sebagai penunjang sumber daya manusia yang sehat dan kuat. Laporan arus kas yang telah disusun akan dipublikasikan oleh perusahaan yang terdaftar dalam sub sektor farmasi merupakan salah satu wujud pertanggungjawaban atas penggunaan kas dari modal yang telah diberikan para investor. Selain itu, laporan arus kas juga bermanfaat bagi para stakeholders lainnya seperti pihak manajemen yang dapat

\section{JIAKES}

$$
\begin{array}{r}
\text { Jurnal Ilmiah Akuntansi } \\
\text { Kesatuan } \\
\text { Vol. } 8 \text { No. 1, 2020 } \\
\text { pg. 57-68 } \\
\text { IBI Kesatuan } \\
\text { ISSN 2337-7852 } \\
\text { E-ISSN } 2721-3048
\end{array}
$$


Financial

Performance in

Pharmacy

mengambil keputusan operasional perusahaan berdasarakan hasil dari analisis laporan arus kas. Laporan arus kas bermanfaat untuk menilai kinerja keuangan perusahaan. Menurut IAI dalam PSAK 2 (2018, paragraf 6 ; 2.2) : Setara kas (cash equivalent) adalah investasi yang sifatnya sangat likuid, berjangka pendek, yang dengan cepat dapat segera dikonversikan menjadi kas dalam jumlah yang dapat ditentukan dan memiliki risiko perubahan nilai yang sangat signifikan. Entitas menyajikan arus kas dari aktivitas operasi, investasi, dan pendanaan dengan cara yang paling sesuai dengan bisnisnya. Klasifikasi arus kas berdasarkan aktivitas menyediakan informasi yang memungkinkan pengguna untuk menilai dampak aktivitas tersebut terhadap posisi keuangan entitas serta terhadap jumlah kas dan setara kas. informasi ini dapat juga digunakan untuk mengevaluasi hubungan di antara ketiga aktivitas tersebut

\section{METODE PENELITIAN}

Jenis data yang digunakan dalam penelitian ini yaitu data sekunder. Data Sekunder yang dipilih harus mencakup beberapa kriteria tertentu, yaitu :

1. Perusahaan merupakan emiten sub sektor farmasi yang telah listing di Bursa Efek selama tahun 2017-2019;

2. Perusahaan rutin membagikan dividen kas selama tahun 2017, 2018, dan 2019;

3. Memiliki kelengkapan informasi keuangan yang dibutuhkan dalam penelitian dan telah diaudit dan telah dipublikasikan;

4. Memiliki tahun buku per 31 Desember;

5. Melaporkan arus kas menggunakan metode langsung

Menurut Sugiyono (2018, 225), "Sumber sekunder merupakan sumber yang tidak langsung memberikan data kepada pengumpul data, misalnya lewat orang lain atau lewat dokumen." Data sekunder didapatkan dari situs web masing-masing perusahaan, serta didapatkan juga melalui Bursa Efek Indonesia dengan mengakses internet di www.idx.co.id dan memilih masing-masing tiap perusahaan sub sektor farmasi yang telah memenuhi kriteria. Periode laporan keuangan yang digunakan selama tiga periode yaitu dari tahun 2017 - 2019. Selain itu, data sekunder yang digunakan dalam penelitian ini berasal dari penelitian kepustakaan (library Research) dengan mendapatkan data dari buku-buku literatur penunjang terkait ; searching informasi yang berkaitan dengan penelitian melalui internet; dan bebagai informasi terkait dari penelitian sebelumnya.

Penelitian yang digunakan oleh penulis menggunakan analisis deskriptif kualitatif. Penelitian ini ditujukan untuk menggambarkan tentang analisis laporan arus kas terhadap kinerja keuangan perusahaan. Laporan arus kas dianalisis berdasarkan rasio arus kas untuk mengetahui kinerja perusahaan sub sektor farmasi yang telah terdaftar di Bursa Efek Indonesia.

Tabel 1 Operasionalisasi Variabel

\begin{tabular}{|l|l|}
\hline \multicolumn{1}{|c|}{ Variabel / Sub Variabel } & \multicolumn{1}{c|}{ Indikator } \\
\hline Analisis laporan arus kas (X) & $\begin{array}{l}\text { - Arus kas dari aktivitas operasi } \\
\text { - Arus kas dari aktivitas investasi } \\
\text { - Arus kas dari aktivitas pendanaan }\end{array}$ \\
\hline Kinerja keuangan perusahaan (Y) & $\begin{array}{l}\text { - Rasio Likuiditas dan Solvabilitas } \\
\text { - Rasio Capital Expenditures dan } \text { Investasi } \\
\text { - Cash Flow Return Ratio }\end{array}$ \\
\hline
\end{tabular}

HASIL DAN PEMBAHASAN

Tabel 2 Daftar Perusahaan

\begin{tabular}{|c|l|}
\hline Kode & Nama Perusahaan \\
\hline KAEF & PT Kimia Farma (Persero) Tbk \\
\hline KLBF & PT Kalbe Farma Tbk \\
\hline TSPC & PT Tempo Scan Pacific Tbk \\
\hline DVLA & PT Darya-Varia Laboratoria Tbk \\
\hline
\end{tabular}


Penelitian ini akan melihat kinerja keuangan perusahaan dengan menganalisa laporan arus kas pada perusahaan sub sektor farmasi yang terdaftar di Bursa Efek Indonesia (BEI) dengan total perusahaan sebanyak empat perusahaan sebagaimana dalam Tabel 2.

\section{Pembahasan}

\section{A. Analisis Laporan Arus Kas dalam Menilai Kinerja Keuangan}

Dalam menganalisis laporan arus kas, perhitungan serta interpretasi rasio merupakan salah satu alat yang banyak digunakan. Adapun analisis laporan arus kas yang dilakukan untuk mengetahui kinerja keuangan dari kelima perusahaan sub sektor farmasi adalah :

\section{a) Rasio Likuiditas dan Solvabilitas}

1. Rasio Likuiditas :

a. Current Cash Debt Coverage

Rumus current cash debt coverage ratio yaitu :

Current Cash Debt Coverage $=\frac{\text { CFO }}{\text { Average Current Liabilities }}$

i. PT Kimia Farma (Persero) Tbk

Tabel 3 Hasil Perhitungan Current Cash Debt Coverage PT Kimia Farma (Persero) Tbk (Dalam Ribuan Rupiah)

\begin{tabular}{|c|c|c|c|}
\hline Tahun & CFO & Average Current Liabilities & $\%$ \\
\hline 2017 & 5.241 .244 & 2.125 .220 .506 & $0,25 \%$ \\
\hline 2018 & 171.669 .100 & 3.650 .037 .292 & $4,70 \%$ \\
\hline 2019 & -1.853 .834 .642 & 6.068 .991 .358 & $-30,55 \%$ \\
\hline \multicolumn{3}{|c|}{ Rata-Rata } & $-8,53 \%$ \\
\hline
\end{tabular}

(Sumber : Data diolah 2020)

ii. PT Kalbe Farma Tbk

Tabel 4 Hasil Perhitungan Current Cash Debt Coverage PT Kalbe Farma Tbk

Dalam Ribuan Rupiah

\begin{tabular}{|l|l|l|c|}
\hline Tahun & \multicolumn{1}{|c|}{ CFO } & \multicolumn{1}{|c|}{ Average Current Liabilities } & $\%$ \\
\hline 2017 & 2.008 .316 .536 & 2.272 .248 .899 & $88,38 \%$ \\
\hline 2018 & 2.770 .775 .949 & 2.256 .751 .742 & $122,78 \%$ \\
\hline 2019 & 2.502 .968 .822 & 2.431 .638 .139 & $102,93 \%$ \\
\hline \multicolumn{4}{|c|}{ Rata-Rata } \\
\hline
\end{tabular}

(Sumber : Data diolah 2020)

iii. PT Tempo Scan Pacific Tbk

Tabel 5 Hasil Perhitungan Current Cash Debt Coverage

PT Tempo Scan Pacific Tbk (Dalam Ribuan Rupiah)

\begin{tabular}{|c|c|c|c|}
\hline Tahun & CFO (Cash Flow from Operation) & Average Current Liabilities & $\%$ \\
\hline 2017 & 544.164 .331 & 1.828 .017 .312 & $29,77 \%$ \\
\hline 2018 & 389.088 .124 & 2.020 .848 .219 & $19,25 \%$ \\
\hline 2019 & 889.775 .270 & 1.996 .341 .670 & $44,57 \%$ \\
\hline \multicolumn{2}{|c|}{ Rata-Rata } & $31,20 \%$ \\
\hline
\end{tabular}

(Sumber : Data diolah 2020)

iv. PT Darya-Varia Laboratoria Tbk

Tabel 6 Hasil Perhitungan Current Cash Debt Coverage

PT Darya-Varia Laboratoria Tbk (Dalam Ribuan Rupiah)

\begin{tabular}{|c|c|c|c|}
\hline Tahun & CFO (Cash Flow from Operation) & Average Current Liabilities & $\%$ \\
\hline 2017 & 230.738 .193 & 408.025 .188 & $56,55 \%$ \\
\hline 2018 & 26.628 .428 & 429.080 .116 & $6,21 \%$ \\
\hline 2019 & 272.538 .844 & 427.990 .702 & $63,68 \%$ \\
\hline \multicolumn{2}{|c|}{ Rata-Rata } & $42,14 \%$ \\
\hline
\end{tabular}

(Sumber : Data diolah 2020) 
Financial

Performance in

Pharmacy

$\underline{60}$
Tabel 7 Hasil Perhitungan Current Cash Debt Coverage Ratio

\begin{tabular}{|c|c|c|c|c|}
\hline \multirow{2}{*}{ Perusahaan } & \multicolumn{3}{|c|}{ Tahun } & \multirow{2}{*}{ Rata-Rata } \\
\cline { 2 - 5 } & 2017 & 2018 & 2019 & \\
\hline PT Kimia Farma (Persero) Tbk & $0,25 \%$ & $4,70 \%$ & $-30,55 \%$ & $-8,53 \%$ \\
\hline PT Kalbe Farma Tbk & $88,38 \%$ & $122,78 \%$ & $102,93 \%$ & $104,70 \%$ \\
\hline PT Tempo Scan Pacific Tbk & $29,77 \%$ & $19,25 \%$ & $44,57 \%$ & $31,20 \%$ \\
\hline PT Darya-Varia Laboratoria Tbk & $56,55 \%$ & $6,21 \%$ & $63,68 \%$ & $42,14 \%$ \\
\hline
\end{tabular}

(Sumber : Data diolah 2020)

Dari hasil perhitungan Current Cash Debt Coverage Ratio keempat perusahaan tersebut, terlihat bahwa PT Kalbe Farma Tbk dan PT Tempo Scan Pacific Tbk menunujukan hasil yang baik karena memiliki rata-rata rasio di atas $40 \%$. PT Tempo Scan menunjukan hasil Current Cash Debt Coverage Ratio yang kurang baik karena memiliki hasil rata-rata kurang dari 40\% dan PT Kimia Farma (Persero) belum dapat menjamin kewajiban lancarnya dengan menggunakan $\mathrm{CFO}$ karena memiliki hasil rata-rata rasio negatif.

b. Cash Dividend Coverage

Rumus :

Cash Dividend Coverage $=\frac{C F O}{\text { Dividen Dibayar }}$

i. PT Kimia Farma (Persero) Tbk

Tabel 8 Hasil Perhitungan Cash Dividend Coverage Ratio

PT Kimia Farma (Persero) Tbk Dalam Ribuan Rupiah

\begin{tabular}{|c|c|c|c|}
\hline \multirow{2}{*}{ Tahun } & CFO (Cash Flow from Operation) & Dividen Dibayar & Rasio (kali) \\
\hline 2017 & 5.241 .244 & 53.485 .020 & 0,10 \\
\hline 2018 & 171.669 .100 & 182.809 .821 & 0,94 \\
\hline 2019 & -1.853 .834 .642 & 123.280 .415 & $-15,04$ \\
\hline \multicolumn{3}{|c|}{ Rata-Rata } & $-4,67$ \\
\hline
\end{tabular}

(Sumber : Data diolah 2020)

ii. PT Kalbe Farma Tbk

Tabel 9 Hasil Perhitungan Cash Dividend Coverage Ratio PT Kalbe Farma Tbk (Dalam Ribuan Rupiah)

\begin{tabular}{|c|c|c|c|}
\hline \multirow{2}{*}{ Tahun } & CFO (Cash Flow from Operation) & Dividen Dibayar & Rasio (kali) \\
\hline 2017 & 2.008 .316 .536 & 1.047 .790 .983 & 1,92 \\
\hline 2018 & 2.770 .775 .949 & 1.190 .617 .266 & 2,33 \\
\hline 2019 & 2.502 .968 .822 & 1.252 .864 .181 & 2,00 \\
\hline \multicolumn{3}{|c|}{ Rata-Rata } & 2,08 \\
\hline
\end{tabular}

(Sumber : Data diolah 2020)

iii. PT Tempo Scan Pacific Tbk

Tabel 10 Hasil Perhitungan Cash Dividend Coverage Ratio

PT Tempo Scan Pacific Tbk

Dalam Ribuan Rupiah

\begin{tabular}{|c|c|c|c|}
\hline Tahun & CFO (Cash Flow from Operation) & Dividen Dibayar & Rasio (kali) \\
\hline 2017 & 544.164 .331 & 225.184 .463 & 2,42 \\
\hline 2018 & 389.088 .124 & 198.218 .837 & 1,96 \\
\hline 2019 & 889.775 .270 & 210.003 .465 & 4,24 \\
\hline \multicolumn{3}{|c|}{ Rata-Rata } & 2,87 \\
\hline
\end{tabular}

(Sumber : Data diolah 2020) 
iv. PT Darya-Varia Laboratoria Tbk

Tabel 11 Hasil Perhitungan Cash Dividend Coverage Ratio

PT Darya-Varia Laboratoria Tbk (Dalam Ribuan Rupiah)

\begin{tabular}{|c|c|c|c|}
\hline Tahun & CFO (Cash Flow from Operation) & Dividen Dibayar & Rasio (kali) \\
\hline 2017 & 230.738 .193 & 111.592 .530 & 2,07 \\
\hline 2018 & 26.628 .428 & 119.406 .233 & 0,22 \\
\hline 2019 & 272.538 .844 & 119.618 .582 & 2,28 \\
\hline \multicolumn{3}{|c|}{ Rata-Rata } & 1,52 \\
\hline
\end{tabular}

(Sumber : Data diolah 2020)

Tabel 12 Hasil Perhitungan Current Cash Dividend Coverage Ratio

\begin{tabular}{|l|c|c|c|c|}
\hline \multirow{2}{*}{\multicolumn{1}{|c|}{ Perusahaan }} & \multicolumn{3}{c|}{ Tahun } & \multirow{2}{*}{ Rata-Rata } \\
\cline { 2 - 4 } & 2017 & 2018 & 2019 & \\
\hline PT Kimia Farma (Persero) Tbk & 0,10 & 0,94 & $-15,04$ & $-4,67$ \\
\hline PT Kalbe Farma Tbk & 1,92 & 2,33 & 2,00 & 2,08 \\
\hline PT Tempo Scan Pacific Tbk & 2,42 & 1,96 & 4,24 & 2,87 \\
\hline PT Darya-Varia Laboratoria Tbk & 2,07 & 0,22 & 2,28 & 1,52 \\
\hline
\end{tabular}

(Sumber : Data diolah 2020)

Dari hasil perhitungan current cash dividend coverage ratio selama periode 2017-2019 keempat perusahaan tersebut, terlihat bahwa kemampuan CFO perusahaan untuk membayar dividen terbesar dimiliki oleh PT Tempo Scan Pacific Tbk. PT Kimia Farma (Persero) Tbk memiliki nilai current cash dividend coverage ratio negatif yang menunjukan bahwa $\mathrm{CFO}$ yang dimiliki perusahaan tidak dapat digunakan untuk membayar dividen.

\section{Rasio Solvabilitas}

a. Cash Long-term Debt Coverage Ratio

Rumus :

Cash Long - term Debt Coverage $=\frac{C F O}{\text { Average Total Liablities }}$

i. PT Kimia Farma (Persero) Tbk

Tabel 13 Hasil Perhitungan Cash Long-term Debt Coverage Ratio PT Kimia Farma (Persero) Tbk (Dalam Ribuan Rupiah)

\begin{tabular}{|c|c|c|c|}
\hline Tahun & $\begin{array}{c}\text { CFO (Cash Flow from } \\
\text { Operation) }\end{array}$ & $\begin{array}{c}\text { Average Total } \\
\text { Liabilities }\end{array}$ & $\%$ \\
\hline 2017 & 5.241 .244 & 3.169 .664 .291 & $0,17 \%$ \\
\hline 2018 & 171.669 .100 & 5.590 .503 .124 & $3,07 \%$ \\
\hline 2019 & -1.853 .834 .642 & 9.061 .391 .551 & $-20,46 \%$ \\
\hline \multicolumn{3}{|c|}{ Rata-Rata } & $5,74 \%$ \\
\hline
\end{tabular}

(Sumber : Data diolah 2020)

ii. PT Kalbe Farma Tbk

Tabel 14 Hasil Perhitungan Cash Long-term Debt Coverage Ratio PT Kalbe Farma Tbk (Dalam Ribuan Rupiah)

\begin{tabular}{|l|l|l|l|}
\hline Tahun & CFO (Cash Flow from Operation) & Average Total Liabilities & $\%$ \\
\hline 2017 & 2.008 .316 .536 & 2.742 .184 .852 & $73,24 \%$ \\
\hline 2018 & 2.770 .775 .949 & 2.786 .909 .491 & $99,42 \%$ \\
\hline 2019 & 2.502 .968 .822 & 3.205 .377 .868 & $78,09 \%$ \\
\hline \multicolumn{3}{|c|}{ Rata-Rata } & $83,58 \%$ \\
\hline
\end{tabular}

(Sumber : Data diolah 2020) 
Financial

Performance in

Pharmacy

$\underline{62}$

b) Rasio Capital Expenditures dan Investasi

Rasio Capital Expenditures dan Investasi bermanfaat untuk menilai apakah perusahaan dapat memenuhi aktiva modalnya (capital asset) dan financial expenditurenya untuk dapat meningkatkan basis aktivanya (asset base). Dwi Prastowo $(2014,155)$.

a. Investment / CFO Plus Finance Ratio

Rumus :

Investment or CFO Plus Finance Ratio $=\frac{\text { Net Cash Flow from Investing }(C F I)}{\text { Net Cash Flow from Operating }(C F O)}$

i. PT Kimia Farma (Persero) Tbk

Tabel 17

Hasil Perhitungan Cash Long-term Debt Coverage Ratio

\begin{tabular}{|l|r|r|r|r|}
\hline \multirow{2}{*}{ Perusahaan } & \multicolumn{3}{|c|}{ Tahun } & \multirow{2}{*}{ Rata-Rata } \\
\cline { 2 - 4 } & 2017 & \multicolumn{1}{|c|}{2018} & \multicolumn{1}{c|}{2019} & \\
\hline PT Kimia Farma (Persero) Tbk & $0,17 \%$ & $3,07 \%$ & $-20,46 \%$ & $-5,74 \%$ \\
\hline PT Kalbe Farma Tbk & $73,24 \%$ & $99,42 \%$ & $78,09 \%$ & $83,58 \%$ \\
\hline PT Tempo Scan Pacific Tbk & $25,29 \%$ & $16,25 \%$ & $35,46 \%$ & $25,66 \%$ \\
\hline PT Darya-Varia Laboratoria Tbk & $47,26 \%$ & $5,29 \%$ & $54,16 \%$ & $35,57 \%$ \\
\hline
\end{tabular}

(Sumber : Data diolah 2020)

Dilihat dari tabel 16 hasil perhitungan cash long-term debt coverage ratio periode 2017-2019 keempat perusahaan tersebut, terlihat PT Kalbe Farma (a) rasio tertinggi yang menunjukan jumlah persentase kewajiban perusahaan yang dijamin oleh CFO. Sementara itu, PT Kimia Farma (Persero) belum dapat menjamin kewajibannya hanya dengan menggunakan $\mathrm{CFO}$ karena memiliki hasil rata-rata rasio negatif.

$$
\begin{gathered}
\text { and Financing Activities (CFF) } \\
\text { a. }
\end{gathered}
$$

Tabel 18 Hasil Perhitungan Investment / CFO Plus Finance Ratio PT Kimia Farma (Persero) Tbk (Dalam Ribuan Rupiah)

\begin{tabular}{|c|c|c|c|c|}
\hline Tahun & $\begin{array}{l}\text { CFI (Cash Flow } \\
\text { from Investing) }\end{array}$ & $\begin{array}{l}\text { CFO (Cash Flow } \\
\text { from Operation) }\end{array}$ & $\begin{array}{l}\text { CFF (Cash Flow } \\
\text { From Financing) }\end{array}$ & $\%$ \\
\hline 2017 & 810.236 .662 & 5.241 .244 & 1.146 .948 .511 & $70,32 \%$ \\
\hline 2018 & 1.562 .904 .871 & 171.669 .100 & 2.322 .930 .108 & $62,65 \%$ \\
\hline 2019 & 2.124 .681 .095 & -1.853 .834 .642 & 3.275 .100 .904 & $149,49 \%$ \\
\hline \multicolumn{4}{|c|}{ Rata-Rata } & $94,16 \%$ \\
\hline
\end{tabular}

(Sumber : Data diolah 2020) 
ii. PT Kalbe Farma Tbk

Tabel 19 Hasil Perhitungan Investment / CFO Plus Finance Ratio PT Kalbe Farma Tbk (Dalam Ribuan Rupiah)

\begin{tabular}{|c|c|c|c|c|}
\hline Tahun & $\begin{array}{l}\text { CFI (Cash Flow } \\
\text { from Investing) }\end{array}$ & $\begin{array}{l}\text { CFO (Cash Flow } \\
\text { from Operation) }\end{array}$ & $\begin{array}{l}\text { CFF (Cash Flow } \\
\text { From Financing) }\end{array}$ & $\%$ \\
\hline 2017 & 1.113 .563 .322 & 2.008 .316 .536 & -976.386 .871 & $107,91 \%$ \\
\hline 2018 & 1.289 .828 .517 & 2.770 .775 .949 & -1.139 .657 .726 & $79,08 \%$ \\
\hline 2019 & 1.900 .541 .454 & 2.502 .968 .822 & -706.915 .285 & $105,82 \%$ \\
\hline \multicolumn{4}{|c|}{ Rata-Rata } & $97,60 \%$ \\
\hline
\end{tabular}

(Sumber : Data diolah 2020)

iii. PT Tempo Scan Pacific Tbk

Tabel 20 Hasil Perhitungan Investment / CFO Plus Finance Ratio

PT Tempo Scan Pacific Tbk (Dalam Ribuan Rupiah)

\begin{tabular}{|c|c|c|c|c|}
\hline \multirow{2}{*}{ Tahun } & $\begin{array}{c}\text { CFI (Cash Flow } \\
\text { from Investing) }\end{array}$ & $\begin{array}{c}\text { CFO (Cash Flow } \\
\text { from Operation) }\end{array}$ & $\begin{array}{c}\text { CFF (Cash Flow } \\
\text { From Financing) }\end{array}$ & $\%$ \\
\hline 2017 & 276.561 .890 & 544.164 .331 & -11.619 .328 & $51,93 \%$ \\
\hline 2018 & 435.278 .569 & 389.088 .124 & -59.827 .253 & $132,20 \%$ \\
\hline 2019 & 365.374 .820 & 889.775 .270 & -150.246 .374 & $49,41 \%$ \\
\hline \multicolumn{5}{|c|}{ Rata-Rata } \\
\hline
\end{tabular}

(Sumber : Data diolah 2020)

iv. PT Darya-Varia Laboratoria Tbk

Tabel 21 Hasil Perhitungan Investment / CFO Plus Finance Ratio

PT Darya-Varia Laboratoria Tbk (Dalam Ribuan Rupiah)

\begin{tabular}{|c|c|c|c|c|}
\hline Tahun & $\begin{array}{l}\text { CFI (Cash Flow } \\
\text { from Investing) }\end{array}$ & $\begin{array}{l}\text { CFO (Cash Flow } \\
\text { from Operation) }\end{array}$ & $\begin{array}{l}\text { CFF (Cash Flow } \\
\text { From Financing) }\end{array}$ & $\%$ \\
\hline 2017 & 41.309 .660 & 230.738 .193 & -111.592 .530 & $34,67 \%$ \\
\hline 2018 & 59.255 .040 & 26.628 .428 & -119.362 .345 & $-63,90 \%$ \\
\hline 2019 & 125.230 .506 & 272.538 .844 & -113.382 .669 & $78,68 \%$ \\
\hline & & ta-Rata & & $16,49 \%$ \\
\hline
\end{tabular}

(Sumber : Data diolah 2020)

Tabel 22 Hasil Perhitungan Investment / CFO Plus Finance Ratio

\begin{tabular}{|l|r|r|r|r|}
\hline \multirow{2}{*}{ Perusahaan } & \multicolumn{3}{|c|}{ Tahun } & \multirow{2}{*}{ Rata-Rata } \\
\cline { 2 - 5 } & \multicolumn{1}{|c|}{2017} & \multicolumn{1}{|c|}{2018} & \multicolumn{1}{c|}{2019} & \\
\hline PT Kimia Farma (Persero) Tbk & $70,32 \%$ & $62,65 \%$ & $149,49 \%$ & $94,16 \%$ \\
\hline PT Kalbe Farma Tbk & $107,91 \%$ & $79,08 \%$ & $105,82 \%$ & $97,60 \%$ \\
\hline PT Tempo Scan Pacific Tbk & $51,93 \%$ & $132,20 \%$ & $49,41 \%$ & $77,85 \%$ \\
\hline PT Darya-Varia Laboratoria Tbk & $34,67 \%$ & $-63,90 \%$ & $78,68 \%$ & $16,49 \%$ \\
\hline
\end{tabular}

(Sumber : Data diolah 2020)

Dilihat dari tabel 21 hasil perhitungan Investment / CFO Plus Finance Ratio periode 2017-2019 keempat perusahaan tersebut, terlihat PT Darya-Varia Laboratoria Tbk memiliki nilai rata-rata rasio terendah. Sementara itu, PT Kalbe Farma Tbk memiliki nilai rata-rata rasio tertinggi. Dwi Prastowo (2014, 156) dalam buku Analisis Laporan Keuangan Konsep dan Aplikasi Edisi Ketiga menyatakan bahwa, semakin rendah investment / CFO plus finance ratio maka semakin baik karena menunjukan bahwa porsi investasi yang dibiayai dari aktivitas operasi dan pendanaan juga rendah.

b. Operations / Investment Ratio

Rumus :

Operations or Investment Ratio $=\frac{C F O}{C F I}$ 
Financial

Performance in

Pharmacy

$\underline{64}$ i. PT Kimia Farma (Persero) Tbk

Tabel 23 Hasil Perhitungan Operations / Investment Ratio PT Kimia Farma (Persero) Tbk (Dalam Ribuan Rupiah)

\begin{tabular}{|c|c|c|c|}
\hline Tahun & $\begin{array}{c}\text { CFO (Cash Flow from } \\
\text { Operation) }\end{array}$ & $\begin{array}{c}\text { CFI (Cash Flow from } \\
\text { Investing) }\end{array}$ & $\%$ \\
\hline 2017 & 5.241 .244 & 810.236 .662 & $0,65 \%$ \\
\hline 2018 & 171.669 .100 & 1.562 .904 .871 & $10,98 \%$ \\
\hline 2019 & -1.853 .834 .642 & 2.124 .681 .095 & $-87,25 \%$ \\
\hline \multicolumn{3}{|c|}{ Rata-Rata } & $-25,21 \%$ \\
\hline
\end{tabular}

(Sumber : Data diolah 2020)

ii. PT Kalbe Farma Tbk

Tabel 24 Hasil Perhitungan Operations / Investment Ratio PT Kalbe Farma Tbk (Dalam Ribuan Rupiah)

\begin{tabular}{|c|c|c|c|}
\hline Tahun & $\begin{array}{c}\text { CFO (Cash Flow from } \\
\text { Operation) }\end{array}$ & $\begin{array}{c}\text { CFI (Cash Flow from } \\
\text { Investing) }\end{array}$ & $\%$ \\
\hline 2017 & 2.008 .316 .536 & 1.113 .563 .322 & $180,35 \%$ \\
\hline 2018 & 2.770 .775 .949 & 1.289 .828 .517 & $214,82 \%$ \\
\hline 2019 & 2.502 .968 .822 & 1.900 .541 .454 & $131,70 \%$ \\
\hline \multicolumn{3}{|c|}{ Rata-Rata } & $175,62 \%$ \\
\hline
\end{tabular}

(Sumber : Data diolah 2020)

iii. PT Tempo Scan Pacific Tbk

Tabel 25 Hasil Perhitungan Operations / Investment Ratio

PT Tempo Scan Pacific Tbk (Dalam Ribuan Rupiah)

\begin{tabular}{|c|c|c|c|}
\hline Tahun & $\begin{array}{c}\text { CFO (Cash Flow from } \\
\text { Operation) }\end{array}$ & $\begin{array}{c}\text { CFI (Cash Flow from } \\
\text { Investing) }\end{array}$ & $\%$ \\
\hline 2017 & 544.164 .331 & 276.561 .890 & $196,76 \%$ \\
\hline 2018 & 389.088 .124 & 435.278 .569 & $89,39 \%$ \\
\hline 2019 & 889.775 .270 & 365.374 .820 & $243,52 \%$ \\
\hline \multicolumn{3}{|c|}{ Rata-Rata } & $176,56 \%$ \\
\hline
\end{tabular}

(Sumber : Data diolah 2020)

iv. PT Darya-Varia Laboratoria Tbk

Tabel 26 Hasil Perhitungan Operations / Investment Ratio

Dalam Ribuan Rupiah

\begin{tabular}{|c|c|c|c|}
\hline Tahun & $\begin{array}{c}\text { CFO (Cash Flow from } \\
\text { Operation) }\end{array}$ & $\begin{array}{c}\text { CFI (Cash Flow from } \\
\text { Investing) }\end{array}$ & $\%$ \\
\hline 2017 & 230.738 .193 & 41.309 .660 & $558,56 \%$ \\
\hline 2018 & 26.628 .428 & 59.255 .040 & $44,94 \%$ \\
\hline 2019 & 272.538 .844 & 125.230 .506 & $217,63 \%$ \\
\hline \multicolumn{3}{|c|}{ Rata-Rata } & $273,71 \%$ \\
\hline
\end{tabular}

(Sumber : Data diolah 2020)

Tabel 27 Hasil Perhitungan Operations / Investment Ratio

\begin{tabular}{|c|c|c|c|c|}
\hline \multirow{2}{*}{ Perusahaan } & \multicolumn{3}{|c|}{ Tahun } & Rata- \\
\hline & 2017 & 2018 & 2019 & \\
\hline PT Kimia Far & $0,65 \%$ & $10,98 \%$ & $-87,25 \%$ & $-25,21 \%$ \\
\hline PT Kalbe Farn & $30,35 \%$ & 214, & 131, & $175,62 \%$ \\
\hline PT Tempo Sca & $196,76 \%$ & $89,39 \%$ & $243,52 \%$ & $176,56 \%$ \\
\hline PT Darya-Varia Laboratoria & $558,56 \%$ & $44,94 \%$ & $217,63 \%$ & $273,71 \%$ \\
\hline
\end{tabular}

(Sumber : Data diolah 2020)

Dilihat dari tabel 26, dari keempat perusahaan PT Darya-Varia Laboratoria Tbk memiliki rata-rata angka Operations / Investment Ratio tertinggi, yaitu sebesar 273,71\%. Rata-rata angka operations / investment ratio terendah dimiliki oleh PT Kimia Farma (Persero) Tbk yaitu sebesar -25,21\%. Dwi 
Prastowo $(2014,157)$ dalam buku Analisis Laporan Keuangan Konsep dan Aplikasi Edisi Ketiga menyatakan bahwa, perbandingan antara CFO dan CFI dapat menilai potensi perusahaan dalam melakukan ekspansi pendanaan dari sumber dana intern. Semakin tinggi angka Operations / Investment Ratio maka berarti perusahaan semakin tidak harus menggantungkan diri pada sumber pembiayaan ekstern.

\section{c) Cash Flow Return Ratio}

a. Cash Flow to Net Income Ratio

Cash Flow to Net Income Ratio $=\frac{\text { CFO }}{\text { Laba Bersih }}$

i. PT Kimia Farma (Persero) Tbk

Tabel 28 Hasil Perhitungan Cash Flow to Net Income Ratio

PT Kimia Farma (Persero) Tbk (Dalam Ribuan Rupiah)

\begin{tabular}{|c|c|c|c|}
\hline Tahun & CFO (Cash Flow from Operation) & Laba Bersih & $\%$ \\
\hline 2017 & 5.241 .244 & 331.707 .917 & $1,58 \%$ \\
\hline 2018 & 171.669 .100 & 535.085 .322 & $32,08 \%$ \\
\hline 2019 & -1.853 .834 .642 & 15.890 .439 & $-11666,35 \%$ \\
\hline \multicolumn{3}{|c|}{ Rata-Rata } & $-3877,56 \%$ \\
\hline
\end{tabular}

(Sumber : Data diolah 2020)

ii. PT Kalbe Farma Tbk

Tabel 29 Hasil Perhitungan Cash Flow to Net Income Ratio PT Kalbe Farma Tbk (Dalam Ribuan Rupiah)

\begin{tabular}{|c|c|c|c|}
\hline Tahun & CFO (Cash Flow from Operation) & Laba Bersih & $\%$ \\
\hline 2017 & 2.008 .316 .536 & 2.453 .251 .411 & $81,86 \%$ \\
\hline 2018 & 2.770 .775 .949 & 2.497 .261 .965 & $110,95 \%$ \\
\hline 2019 & 2.502 .968 .822 & 2.537 .601 .824 & $98,64 \%$ \\
\hline \multicolumn{3}{|c|}{ Rata-Rata } & $97,15 \%$ \\
\hline
\end{tabular}

(Sumber : Data diolah 2020)

iii. PT Tempo Scan Pacific Tbk

Tabel 30 Hasil Perhitungan Cash Flow to Net Income Ratio PT Tempo Scan Pacific Tbk (Dalam Ribuan Rupiah)

\begin{tabular}{|c|c|c|c|}
\hline \multirow{2}{*}{ Tahun } & CFO (Cash Flow from Operation) & Laba Bersih & $\%$ \\
\hline 2017 & 544.164 .331 & 557.339 .582 & $97,64 \%$ \\
\hline 2018 & 389.088 .124 & 540.378 .146 & $72,00 \%$ \\
\hline 2019 & 889.775 .270 & 595.154 .913 & $149,50 \%$ \\
\hline \multicolumn{3}{|c|}{ Rata-Rata } & $106,38 \%$ \\
\hline
\end{tabular}

(Sumber : Data diolah 2020)

iv. PT Darya-Varia Laboratoria Tbk

Tabel 31 Hasil Perhitungan Cash Flow to Net Income Ratio

PT Darya-Varia Laboratoria Tbk (Dalam Ribuan Rupiah)

\begin{tabular}{|c|c|c|c|}
\hline \multirow{2}{*}{ Tahun } & CFO (Cash Flow from Operation) & Laba Bersih & $\%$ \\
\hline 2017 & 230.738 .193 & 162.249 .293 & $142,21 \%$ \\
\hline 2018 & 26.628 .428 & 200.651 .968 & $13,27 \%$ \\
\hline 2019 & 272.538 .844 & 221.783 .249 & $122,89 \%$ \\
\hline \multicolumn{3}{|c|}{ Rata-Rata } & $92,79 \%$ \\
\hline
\end{tabular}

(Sumber : Data diolah 2020) 
Financial

Performance in

Pharmacy

$\underline{66}$
Tabel 32 Hasil Perhitungan Cash Flow to Net Income Ratio

\begin{tabular}{|l|r|r|r|r|}
\hline \multirow{2}{*}{ Perusahaan } & \multicolumn{3}{|c|}{ Tahun } & \multirow{2}{*}{ Rata-Rata } \\
\cline { 2 - 4 } & \multicolumn{1}{|c|}{2017} & \multicolumn{1}{|c|}{2018} & \multicolumn{1}{c|}{2019} & \\
\hline PT Kimia Farma (Persero) Tbk & $1,58 \%$ & $32,08 \%$ & $-11666,35 \%$ & $-3877,56 \%$ \\
\hline PT Kalbe Farma Tbk & $81,86 \%$ & $110,95 \%$ & $98,64 \%$ & $97,15 \%$ \\
\hline PT Tempo Scan Pacific Tbk & $97,64 \%$ & $72,00 \%$ & $149,50 \%$ & $106,38 \%$ \\
\hline PT Darya-Varia Laboratoria Tbk & $142,21 \%$ & $13,27 \%$ & $122,89 \%$ & $92,79 \%$ \\
\hline
\end{tabular}

(Sumber : Data diolah 2020)

Dilihat dari tabel 31, menunjukan bahwa dari keempat perusahaan tersebut, PT Kimia Farma (Persero) Tbk merupakan perusahaan yang memiliki persentase CFO perusahaan terhadap laba terendah.

b. Quality of Sales Ratio

Quality of Sales Ratio $=\frac{\text { Cash From Sales }}{\text { Penjualan }}$

i. PT Kimia Farma (Persero) Tbk

Tabel 33 Hasil Perhitungan Quality of Sales Ratio PT Kimia Farma (Persero) Tbk (Dalam Ribuan Rupiah)

\begin{tabular}{|c|c|c|c|}
\hline Tahun & Cash from Sales & Penjualan & $\%$ \\
\hline 2017 & 6.226 .965 .854 & 6.127 .479 .369 & $101,62 \%$ \\
\hline 2018 & 9.033 .070 .560 & 8.459 .247 .287 & $106,78 \%$ \\
\hline 2019 & 9.284 .213 .271 & 9.400 .535 .476 & $98,76 \%$ \\
\hline \multicolumn{3}{|c|}{ Rata-Rata } & $102,39 \%$ \\
\hline
\end{tabular}

(Sumber : Data diolah 2020)

ii. PT Kalbe Farma Tbk

Tabel 34 Hasil Perhitungan Quality of Sales Ratio

PT Kalbe Farma Tbk (Dalam Ribuan Rupiah)

\begin{tabular}{|c|c|c|c|}
\hline Tahun & Cash from Sales & Penjualan & $\%$ \\
\hline 2017 & 21.749 .971 .834 & 20.182 .120 .167 & $107,77 \%$ \\
\hline 2018 & 22.705 .216 .596 & 21.074 .306 .186 & $107,74 \%$ \\
\hline 2019 & 24.423 .134 .030 & 22.633 .476 .361 & $107,91 \%$ \\
\hline \multicolumn{3}{|c|}{ Rata-Rata } & $107,80 \%$ \\
\hline
\end{tabular}

(Sumber : Data diolah 2020)

iii. PT Tempo Scan Pacific Tbk

Tabel 35 Hasil Perhitungan Quality of Sales Ratio PT Tempo Scan Pacific Tbk (Dalam Ribuan Rupiah)

\begin{tabular}{|c|c|c|c|}
\hline Tahun & Cash from Sales & Penjualan & $\%$ \\
\hline 2017 & 9.283 .545 .373 & 9.565 .462 .045 & $97,05 \%$ \\
\hline 2018 & 10.001 .416 .139 & 10.088 .118 .831 & $99,14 \%$ \\
\hline 2019 & 11.006 .222 .109 & 10.993 .842 .058 & $100,11 \%$ \\
\hline \multicolumn{3}{|c|}{ Rata-Rata } & $98,77 \%$ \\
\hline
\end{tabular}

(Sumber : Data diolah 2020)

iv. PT Darya-Varia Laboratoria Tbk

Tabel 36 Hasil Perhitungan Quality of Sales Ratio PT Darya-Varia Laboratoria Tbk (Dalam Ribuan Rupiah)

\begin{tabular}{|c|c|c|c|}
\hline Tahun & Cash from Sales & Penjualan & $\%$ \\
\hline 2017 & 1.577 .778 .286 & 1.575 .647 .308 & $100,14 \%$ \\
\hline 2018 & 1.612 .271 .777 & 1.699 & $94,86 \%$ \\
\hline 2019 & 1.833 .091 .642 & 1.813 .020 .278 & $101,11 \%$ \\
\hline \multicolumn{3}{|c|}{ Rata-Rata } & $98,70 \%$ \\
\hline
\end{tabular}

(Sumber : Data diolah 2020) 
Tabel 37 Hasil Perhitungan Quality of Sales Ratio

\begin{tabular}{|l|r|r|r|r|}
\hline \multirow{2}{*}{ Perusahaan } & \multicolumn{3}{|c|}{ Tahun } & \multirow{2}{*}{ Rata-Rata } \\
\cline { 2 - 5 } & \multicolumn{1}{|c|}{2017} & \multicolumn{1}{c|}{2018} & \multicolumn{1}{c|}{2019} & \\
\hline PT Kimia Farma (Persero) Tbk & $101,62 \%$ & $106,78 \%$ & $98,76 \%$ & $102,39 \%$ \\
\hline PT Kalbe Farma Tbk & $107,77 \%$ & $107,74 \%$ & $107,91 \%$ & $107,80 \%$ \\
\hline PT Tempo Scan Pacific Tbk & $97,05 \%$ & $99,14 \%$ & $100,11 \%$ & $98,77 \%$ \\
\hline PT Darya-Varia Laboratoria Tbk & $100,14 \%$ & $94,86 \%$ & $101,11 \%$ & $98,70 \%$ \\
\hline
\end{tabular}

(Sumber : Data diolah 2020)

Dilihat dari tabel 36, PT Kalbe Farma Tbk memiliki rata-rata quality of sales ratio yang tertinggi Quality of sales ratio terendah dimiliki oleh PT Darya-Varia Laboratoria Tbk yaitu sebesar 98,70\%.

c. Cash Return on Stockholders' Equity Ratio

i. PT Kimia Farma (Persero) Tbk

Tabel 38 Hasil Perhitungan Cash Return on Stockholders' Equity Ratio PT Kimia Farma (Persero) Tbk Dalam Ribuan Rupiah

\begin{tabular}{|c|c|c|c|}
\hline Tahun & $\begin{array}{c}\text { CFO (Cash Flow from } \\
\text { Operation) }\end{array}$ & $\begin{array}{c}\text { Average Stockholders' } \\
\text { Equity }\end{array}$ & $\%$ \\
\hline 2017 & 5.241 .244 & 2.772 .659 .258 & $0,19 \%$ \\
\hline 2018 & 171.669 .100 & 3.710 .084 .587 & $4,63 \%$ \\
\hline 2019 & -1.853 .834 .642 & 5.779 .592 .448 & $-32,08 \%$ \\
\hline \multicolumn{3}{|c|}{ Rata-Rata } & $-9,09 \%$ \\
\hline
\end{tabular}

(Sumber : Data diolah 2020)

ii. PT Kalbe Farma Tbk

Tabel 39 Hasil Perhitungan Cash Return on Stockholders' Equity Ratio PT Kalbe Farma Tbk Dalam Ribuan Rupiah

\begin{tabular}{|c|c|c|c|}
\hline \multirow{2}{*}{ Tahun } & CFO & Average Stockholders' Equity & $\%$ \\
\hline 2017 & 2.008 .316 .536 & 13.178 .939 .462 & $15,24 \%$ \\
\hline 2018 & 2.770 .775 .949 & 14.594 .313 .290 & $18,99 \%$ \\
\hline 2019 & 2.502 .968 .822 & 16.000 .088 .636 & $15,64 \%$ \\
\hline \multicolumn{3}{|c|}{ Rata-Rata } & $16,62 \%$ \\
\hline
\end{tabular}

(Sumber : Data diolah 2020)

iii. PT Tempo Scan Pacific Tbk

Tabel 40 Hasil Perhitungan Cash Return on Stockholders' Equity Ratio

PT Tempo Scan Pacific Tbk Dalam Ribuan Rupiah

\begin{tabular}{|c|c|c|c|}
\hline Tahun & CFO & Average Stockholders' Equity & $\%$ \\
\hline 2017 & 544.164 .331 & 4.858 .640 .776 & $11,20 \%$ \\
\hline 2018 & 389.088 .124 & 5.257 .428 .240 & $7,40 \%$ \\
\hline 2019 & 889.775 .270 & 5.611 .942 .020 & $15,86 \%$ \\
\hline \multicolumn{3}{|c|}{ Rata-Rata } & $11,49 \%$ \\
\hline
\end{tabular}

(Sumber : Data diolah 2020)

iv. PT Darya-Varia Laboratoria Tbk

Tabel 41 Hasil Perhitungan Cash Return on Stockholders' Equity Ratio

PT Darya-Varia Laboratoria Tbk Dalam Ribuan Rupiah

\begin{tabular}{|c|c|c|c|}
\hline Tahun & CFO & Average Stockholders' Equity & $\%$ \\
\hline 2017 & 230.738 .193 & 1.097 .939 .841 & $21,02 \%$ \\
\hline 2018 & 26.628 .428 & 1.158 .280 .966 & $2,30 \%$ \\
\hline 2019 & 272.538 .844 & 1.253 .170 .426 & $21,75 \%$ \\
\hline \multicolumn{3}{|c|}{ Rata-Rata } & $15,02 \%$ \\
\hline
\end{tabular}

(Sumber : Data diolah 2020) 
Financial

Performance in

Pharmacy

$\underline{68}$
Tabel 42 Hasil Perhitungan Cash Return on Stockholders' Equity Ratio

\begin{tabular}{|c|c|c|c|c|}
\hline \multirow{2}{*}{ Perusahaan } & \multicolumn{3}{|c|}{ Tahun } & \multirow{2}{*}{ Rata-Rata } \\
\cline { 2 - 4 } & 2017 & 2018 & 2019 & \\
\hline PT Kimia Farma (Persero) Tbk & $0,19 \%$ & $4,63 \%$ & $-32,08 \%$ & $-9,09 \%$ \\
\hline PT Kalbe Farma Tbk & $15,24 \%$ & $18,99 \%$ & $15,64 \%$ & $16,62 \%$ \\
\hline PT Tempo Scan Pacific Tbk & $11,20 \%$ & $7,40 \%$ & $15,86 \%$ & $11,49 \%$ \\
\hline PT Darya-Varia Laboratoria Tbk & $21,02 \%$ & $2,30 \%$ & $21,75 \%$ & $15,02 \%$ \\
\hline
\end{tabular}

(Sumber : Data diolah 2020)

Dilihat dari tabel 4.41, PT Kalbe Farma Tbk memiliki rata-rata cash return on stockholders' equity ratio tertinggi. Return on stockholders' equity ratio terendah dimiliki oleh PT Kimia Farma (Persero) Tbk yaitu sebesar -9,09\%. Dwi Prastowo $(2014,161)$ dalam buku Analisis Laporan Keuangan Konsep dan Aplikasi Edisi Ketiga mengungkapkan bahwa gambaran tentang kemampuan perusahaan dalam menghasilkan cash return yang cukup untuk pemegang saham dapat digambarkan oleh cash return on stockholders' equity ratio.

\section{PENUTUP}

Berdasarkan penelitian yang telah dilakukan, dapat disimpulkan bahwa, dari keempat perusahaan farmasi yang diteliti, PT Kalbe Farma Tbk menunjukan hasil kinerja yang baik dibanding perusahaan lainnya. Dari keempat perusahaan farmasi yang di teliti, dalam menyajikan laporan arus kas semua perusahaan menggunakan metode langsung dimana informasi arus kas dari kegiatan operasi perusahaan dikelompokan menjadi dua kategori yaitu arus kas masuk dan arus kas keluar. Selanjutnya, arus kas masuk dan arus kas keluar dirinci lebih lanjut ke dalam penerimaan dan pengeluaran kas sesuai dengan jenisnya.

Hasil perhitungan rasio arus kas menunjukan PT Kalbe Farma Tbk memiliki hasil yang lebih baik bila dibandingkan dengan keempat perusahaan lainnya. Pada rasio cash dividend coverage, PT Tempo Scan Pacific Tbk memiliki hasil yang tertinggi. Pada investment / CFO plus finance ratio PT Darya-Varia Laboratoria Tbk memiliki rasio yang terendah dibandingkan dengan perusahaan lainnya. Pada operations / investment ratio , PT Darya-Varia Laboratoria Tbk memiliki rasio tertinggi dibandingkan dengan perusahaan lainnya. Pada cash flow net income ratio, PT Tempo Scan Pacific Tbk memiliki hasil yang tertinggi.

\section{DAFTAR PUSTAKA}

Amaefule, L.I. , Onyekpere. U.R., Kalu., E.O. 2018. International Financial Reporting Standards and Manufacturing Firms' Financial Performance in Nigeria: A Study of Selected Quoted Firms. International Journal of Accounting and Taxation : Nigeria.

Golestani. H. A., Hosseini, S. M., Mehrjoo,Ehsan. Separating and Merging Cash Flows: Investigating Five-element Cash Flows Statement. International Journal of Economics and Financial Issues : Iran.

Intan, Novita. 2019. Iuran BPJS Naik, Sektor Farmasi Diprediksi Tumbuh Positif. [Internet]. [Diakses pada tanggal 12 September 2019]. Tersedia pada : https://republika.co.id/berita/pxnkgl383/iuran-bpjs-naik-sektor-farmasi-diprediksitumbuh-positif

Kusuma, Retno Ayu. 2018 .Pengertian Kinerja Keuangan Menurut Para Ahli Terlengkap. [Internet]. [Diakses pada tanggal 2 Agustus 2019]. Tersedia pada : https://dosenakuntansi.com/pengertian-kinerja-keuangan

Megi, Sila J. W., Ilat,Vetje, Gerungai,Natalia. 2018. Analisis Rasio Arus Kas Dalam Menilai Kinerja Keuangan Pada PT. PLN (Persero) Wilayah Suluttenggo.Jurnal Riset Akuntansi Going Concern : Suluttenggo.

Mulyani, Sri. 2013. Analisis Rasio Arus Kas Sebagai Alat Pengukur Kinerja Keuangan Perusahaan. Jurnal Dinamika Ekonomi \& Bisnis : Semarang. 